\title{
CRUCIFEROUS VEGETABLES IN CANCER PREVENTION
}

\author{
Pilátová, M. - Chripková, M. - Mojžiš, J. \\ Department of Pharmacology, Faculty of Medicine, PJ Safarik University, Kosice, \\ Slovak republic
}

\begin{abstract}
Epidemiological studies have reported a strong inverse correlation between the intake of cruciferous vegetables and the cancer risk. This association has been found stronger than the association between cancer risk and fruit and vegetable intake in general. Cruciferous vegetables are unique in that they are rich sources of glucosinolates. Hydrolytic degradation of glucosinolates results in the formation of biologically active compounds, including indoles (such as I3C - indole3-carbinol, DIM - diindolylmethane, indole phytoalexins) and isothiocyanates (such as PEITC phenethyl isothiocyanate, SFN - sulforaphane). Some mechanisms, like effect on biotransformation system, induction of cell cycle arrest and apoptosis, and antiangiogenic effect, by which cruciferous vegetables act as chemopreventive agents have been described. Beneficial modulation of oestrogen metabolism with reduced risk of breast and cervical cancer after DIM and I3C supplementation was noted. Despite all health benefit expectation, some studies found that I3C actually promoted or enhanced the development of cancer when administered chronically after the carcinogen (post initiation) to rats. Because the long-term effects of the supplementation of the mentioned compounds on cancer risk in humans are not known, the widespread use of dietary supplements containing natural compounds in humans should be avoided until the potential risks versus benefits are better understood.
\end{abstract}

Key words: cruciferous - vegetable - cancer - prevention - isothiocyanates - sulforaphane indole-3-carbinol

\section{INTRODUCTION}

Cancer is one of the most common conventional causes of death in the developed countries. There are many studies reporting a reduction in cancer risk with increased intake of fruits and vegetables. The primary cancer protective benefit of such a dietary change may not be associated with decreased fat or increased fibre intakes as much as it is with increased intake of non-nutritive dietary components. Many studies report a strong inverse relationship between the intake of cruciferous vegetables and the risk of cancer. This association has been found stronger than the association between cancer risk and fruit and vegetable intake in general. Epidemiological studies have demon- 
strated inverse association between crucifer intake and the incidence of lung, pancreas, bladder, prostate, thyroid, skin, stomach and colon cancer [1]. Cruciferous or Brassica vegetables come from plants in the family known to botanists as Cruciferae or alternatively, Brassicaceae [2] containing about 340 genera and 3,700 species of enormous economic importance. They are good sources of a variety of nutrients and phytochemicals that may work synergistically to help prevent cancer [3]. Plants in the Cruciferae family have flowers with four equal-sized petals in the shape of a 'crucifer' (cross). Brassica is the Latin term for cabbage. Many commonly consumed cruciferous vegetables come from the Brassica genus, including broccoli, Brussels sprouts, cabbage, cauliflower, collard greens, kale, kohlrabi, mustard, rutabaga, turnips, bok choy and Chinese cabbage [4]. Like other vegetables, cruciferous vegetables contain a number of nutrients and phytochemicals with cancer chemopreventive properties. However, cruciferous vegetables are unique in that they are rich sources of glucosinolates, sulphur-containing compounds that are responsible for their pungent aromas and spicy taste [1].

\section{GLUCOSINOLATES AND THEIR HYDROLYSIS PRODUCTS}

Cruciferous vegetables are rich in glucosinolates (GS) and contain different profiles of these compounds. The GS themselves are not biologically active. Myrosinase is the glucosidase enzyme found in the cells of cruciferous vegetables responsible for hydrolysis of GS when raw vegetables are chopped or chewed. This hydrolytic degradation results in the formation of biologically active compounds like indoles (I3C, indole phytoalexins) and ITCs (PEITC, SFN) [2,5,6]. I3C found in a variety of cruciferous vegetables may be converted to a number of derivatives in the acid environment of the stomach $[7,8]$ including a dimer, DIM and the closed ring dimer indolocarbazole (ICZ indolo[3,2-b]carbazole), trimers including the linear and the cyclic trimers and ascorbigen, the condensation product of $\mathrm{I} 3 \mathrm{C}$ and ascorbic acid.

GS are water-soluble compounds that may be released into cooking water. Despite a loss of naturally available myrosinase during cooking, glucosinolates are hydrolysed by native gut bacteria but much less efficiently.

\section{EFFECTS ON BIOTRANSFORMATION SYSTEM}

A mechanism by which dietary ingredients could be of benefit is that they modulate biotransformation in such a manner that carcinogens become less active and thus exert less harm in the target cancer cells.

ITCs in cruciferous vegetables are catalysed by the four major human GSTs: GSTA1-1, GSTP1-1, GSTM1-1 and GSTM2-2. There is increasing evidence that genetic differences in humans may influence the effect of cruciferous vegetable intake on cancer risk. Homozygous individuals with null variants GSTM1 and GSTT1 gene caused by large deletions produce GSTs with lower activity leading to slower elimination and longer exposure to ITCs resulting in their higher protective effect [13]. 
ITCs affect biotransformation enzyme activity by several mechanisms. They induce expression of phase I and phase II enzymes. Consumption of I3C resulting in formation of acid condensation products DIM and ICZ can increase the activity of certain phase I (CYP 1A, CYP 1B) and phase II enzymes (GST, NADPH quinone oxidoreductase, UDP glucuronyl transferases (UGTs) and glutamate cysteine ligase), which play important roles in protecting cells from DNA damage by carcinogens and reactive oxygen species [14].

There are human studies that examined the direct effects of cruciferous vegetable supplementation on metabolism of carcinogens [13,15]. Smokers who consumed 170 $\mathrm{g} / \mathrm{d}(6 \mathrm{oz} / \mathrm{d})$ of watercress had increased activity of UGT leading to significantly increased urinary excretion of glucuronidated nicotine metabolites. Metabolism of cooked meat derived heterocyclic aromatic amines was increased by broccoli and brussels sprouts implicating the induction of both CYP1A2 and phase II enzymes involved in heterocyclic amine metabolism [16].

Some procarcinogens require biotransformation by phase I enzymes to become active carcinogens [18]. Marked I3C-induced increase in CYP1A2 activity, a key enzyme in the carcinogen metabolism, especially aromatic amines, was noted [20]. However, some studies found that I3C actually promoted or enhanced the development of cancer when administered chronically after the carcinogen (post initiation). The ability of I3C to promote or enhance cancer of liver [21, 22] thyroid [23], colon and uterus [24] was noted in experiments with rats. Yoshida et al. [23] suggest that induction of the CYP 1 family in the liver might play a crucial role in promoting the effects of dietary $\mathrm{I} 3 \mathrm{C}$ on cancer development.

\section{EFFECTS ON OESTROGEN METABOLISM AND OESTROGEN ACTIVITY}

Beneficial modulation of oestrogen metabolism correlates with reduced risk of breast and other cancers including cervical and prostate ones [24,25,26,27]. I3C and DIM are considered to be especially valuable in protecting against hormone-dependent cancers such as certain breast, cervical and prostate cancers, due to their ability to favourably influence the human body's balance of oestrogens [28]. The enzymes 2- and 16 - $\alpha$-oestrogen hydroxylase help metabolize oestrogens. One pathway results in estradiol conversion to a less potent form of oestrogen, 2-hydroxyestrone (2-OHE1) while the other pathway increases production of the more toxic oestrogen metabolite 16- $\alpha$ hydroxyestrone (16 $\alpha$-OHE1) [25,29]. I3C and DIM are effective in shifting the metabolism of estradiol to a more beneficial pathway thus reducing levels of toxic $16 \alpha$-OHE1 and increasing levels of protective 2-OHE1 [27,29,30,31]. In controlled clinical trials, oral supplementation with I3C or DIM (300-400 mg/day) has consistently increased urinary 2-OHE1 levels in women [32]. I3C (200-400 mg/day) given to women with cervical intraepithelial neoplasia (CIN - a risk factor for uterine cervix cancer) showed complete regression of CIN in $40 \%$ of the women after 12 weeks, but no women in the placebo group showed regression. A dose-dependent increase in 2-OHE1 levels was recorded. These results suggest that intake of I3C and crucifers rich in I3C may protect against hormone-dependent cancers [33]. 


\section{INDUCTION OF CELL CYCLE ARREST AND APOPTOSIS}

One hallmark of cancer is hyperproliferation due to loss of cell cycle regulatory mechanisms. The key regulators of cell cycle progression are the cyclin-dependent kinases (CDKs), cyclins and CDK inhibitors. SFN-induced cell cycle arrest correlated with an increased expression of cyclins A and B1 along with no detection of antiapoptotic Bcl-2 and increased expression of the proapoptotic protein Bax, the release of cytochrome $c$ and the proteolytic cleavage of poly(ADP-ribose) polymerase were observed in HT29 human colon cancer cells. Misiewicz et al. showed that SFN changes cell growth and induces apoptosis in various cell lines. Effective inhibition of PC-3 human prostate cancer cells proliferation caused by caspase-8- and caspase-9-mediated apoptosis was noted after treatment with SFN [35]. Conaway [36] described the ability of PEITC, SFN and their $N$-acetylcysteine conjugates to inhibit the progression to adenocarcinomas after already developed lung adenomas. The growth of PC-3 xenografts in nude mice was significantly inhibited after oral administration of SFN. Inhibition of PC3 xenograft growth was observed at a dose of SFN which can be generated through dietary intake of cruciferous vegetables. In addition to apoptosis induction, ITCs also showed cell cycle arrest at the $\mathrm{G}_{1}, \mathrm{~S}$ or $\mathrm{G}_{2} / \mathrm{M}$ phases [37, 38, 39]. In vitro experiments with SFN indicate a pronounced role for cell cycle arrest in its anti-cancer properties.

Treatment of MCF-7 breast cancer cells with I3C blocks $\mathrm{G}_{1}$ to $\mathrm{S}$ phase progression was associated with a conversion of the active CDK2 complex to an inactive complex [40]. Moreover, in this cell line, I3C did not affect expression of p21 or p27 CDK inhibitors [41,42]. The $\mathrm{G}_{1}$ cell cycle arrest in prostate cancer cells caused by I3C also noted. However, the specific targets of I3C exhibit both similar and overlapping effects in $\mathrm{LNCaP}$ and PC3 prostate cancer cells compared to MCF-7 breast cancer cells. In androgen-responsive $\mathrm{LNCaP}$ prostate cancer cells, treatment with $\mathrm{I} 3 \mathrm{C}$ decreased expression of CDK6, CDK2-dependent enzymatic activity, and induced the CDK inhibitors p16, p21 and p27 [38].

Another naturally occurring indole-based group in cruciferous vegetables are indole phytoalexins. Cytotoxic effects against various solid tumour and leukemia cell lines in vitro were reported for brassinin, spirobrassinin, camalexin, 1-methoxyspirobrassinol, 1methoxybrassinin and 1-methoxyspirobrassinin [43]. Some synthetic spirobrassinol analogues derived from 1-methoxyspirobrassinol demonstrated higher cytotoxic effect than the traditional alkylating agent melphalan via induction of apoptosis accompanied with significantly higher caspase-3 and -7 activities. DNA-alkylating effect and glutathione-depleting effects that may sensitise cancer cells to alkylating agents of mentioned synthetic compounds was observed as well [44]. Structure and antiproliferative activity relationship study of camalexin showed that the binding of benzene on camalexine structure significantly enhanced its cytotoxic effect [45]. Promising antiproliferative activity for amino analogues of 1-methoxybrassinin and 1-Boc-brassinin was noted [46]. 1-methoxybrassinin exerted the most potent cytotoxicity among tested indole phytoalexins. Induction of apoptosis was described by significant increase in the fraction of cells with a sub- $\mathrm{G}_{0} / \mathrm{G}_{1}$ DNA content [47]. There is only limited knowledge 
about possible antiproliferative effect of these compounds and molecular mechanisms of their antiproliferative effect are not known yet.

\section{INHIBITION OF ANGIOGENESIS}

Angiogenesis is essential for tumour growth and metastasis, which are two major factors that hinder cancer therapy. Endothelial cells play a central role in the tube formation of such neovessels. I3C and DIM significantly inhibited tube formation, but only DIM induced significant increase in apoptosis in tube-forming HUVEC (human umbilical vein endothelial cells). HUVEC treatment with DIM also resulted in activation of the caspase pathway and inactivation of Akt, which plays a key role in cell proliferation, apoptosis, transcription and cell migration [48]. I3C and DIM at the molecular level markedly inactivated extracellular signal regulated kinase $1 / 2$ (ERK 1/2). DIM also reduces the level of hypoxia-inducible factor (HIF)- $1 \alpha$ in hypoxic tumour cell lines, as well as HIF-1 transcriptional activity and inhibited the expression of HIF-1-responsive endogenous genes, resulting in reduced expression of key hypoxia responsive factors, vascular endothelial growth factor (VEGF), furin, enolase-1, glucose transporter-1 and phosphofructokinase. According to this finding we can assume that DIM can decrease the accumulation and activity of the key angiogenesis regulatory factor HIF-1 $\alpha$ in hypoxic tumour cells [49].

Xiao and Singh [50] observed significant inhibition of the capillary-like tube formation by HUVEC and HUVEC migration after PEITC treatment in vitro and ex vivo at pharmacologically achievable concentrations. The PEITC treatment caused a decrease in survival of HUVEC in a concentration and time-dependent manner. The PEITC inhibition effect of angiogenesis in vitro was associated with suppression of VEGF secretion, down-regulation of VEGR receptor 2 protein levels and inactivation of prosurvival Akt.

SFN antiangiogenic effect is due to inhibition of angiogenesis-activating transcription factors such as HIF- $1 \alpha$ and c-Myc, inhibition of basal membrane integrity by reduced production of metalo-proteinase- 2 and reduction of endothelium cell proliferation [51, 52]. Davis et al. [53] described inhibition of angiogenesis by SNF through regulation of FOXO transcription factor (Forkhead box 'Other' proteins play important roles in regulating the expression of genes involved in cell growth, proliferation, differentiation and longevity) in HUVEC. In the presence of SFN, induced FOXO transcriptional activity was noted and followed by inhibition in cell migration and capillary tube formation.

\section{CONCLUSIONS}

Epidemiological studies have shown that crucifers provide an even greater protection against cancer than a diet high in a general mixture of fruits and vegetables. It is becoming clear that glucosinolate breakdown products can influence the initiation and progression of carcinogenesis. Numerous animal and epidemiological studies support 
the activity and scientists keep identifying responsible molecular mechanisms from the anticarcinogenic action. In vivo many ITCs and their metabolites have been found to inhibit the development of chemically induced cancers of the lung, liver, oesophagus, stomach, small intestine, colon and breast in a variety of animal models $[54,55]$. When I3C is administered before or at the same time as the carcinogen, oral $\mathrm{I} 3 \mathrm{C}$ has been found to inhibit the development of cancer in a variety of animal models and tissues, including breast, stomach, colon, lung and liver cancer. However, some animal studies reported contradictory results on animal studies. After I3C treatment promoted or enhanced development of liver, thyroid, colon and uterus cancer was noted in experiments with rats. Because the long-term effects of the supplementation of the mentioned compounds on cancer risk in humans are not known, the widespread use of dietary supplements containing natural compounds in humans should be avoided until the potential risks versus benefits are better understood.

Acknowledgement: The authors' original research is supported by the Slovak Research and Development Agency under the contract No. APVV-0325-07 and by the Slovak Grant Agency for Science (grant No. 1/0302/10 and 1/0304/10).

This work was also partially supported by the Agency of the Slovak Ministry of Education for the Structural Funds of the EU, under projects ITMS: 26220120039.

\section{REFERENCES}

1. KECK, A.S. - FINLEY, J.W.: Cruciferous vegetables: cancer protective mechanisms of glucosinolate hydrolysis products and selenium. Integr Cancer Ther., 2004, p. 5 - 12.

2. HIGDON, J.V. - DELAGE, B. - WILliAMS, D.E. - DASHWOOD, R.H.: Cruciferous vegetables and human cancer risk: epidemiologic evidence and mechanistic basis, Pharmacol Res., 2007, p. 224-236.

3. LIU, R.H.: Potential synergy of phytochemicals in cancer prevention: mechanism of action. J Nutr., 2004, p. 3479-3485.

4. KRISTAL, A.R. - LAMPE, J.W.: Brassica vegetables and prostate cancer risk: a review of the epidemiological evidence. Nutr Cancer, 2002, p. 1 - 9.

5. MCNAUGHTON, S.A. - MARKS, G.C.: Development of a food composition database for the estimation of dietary intakes of glucosinolates, the biologically active constituents of cruciferous vegetables Br J Nutr., 2003, p. 687-697.

6. ZHANG Y.: Cancer-preventive isothiocyanates: measurement of human exposure and mechanism of action. Mutat Res., 2004, p. 173-190.

7. GROSE, K.R. - BJELDANES, L.F.: Oligomerization of indole-3-carbinol in aqueous acid. Chem Res Toxicol., 1992, p.188-193.

8. WANGA, T.Y. - MILNERB, M.J. - MILNERC, J.A. - KIM, Y.S.: Estrogen receptor a as a target for indole-3-carbinol. Journal of Nutr Biochem., 2006, p. 659-664.

9. THORNALLEY, P.J.: Isothiocyanates: mechanism of cancer chemopreventive action. Anti-Cancer Drugs, 2002, p. 331-338

10. NAKAJIMA, M. - YOSHIDA, R. - SHIMADA, N. - YAMAZAKI, H. - YOKOI T.: Inhibition and inactivation of human cytochrome $\mathrm{P} 450$ isoforms by phenethyl isothiocyanate. Drug Metab Disp., 2001, p. 1110-1113.

11. GOOSEN, T.C. - MILLS, D.E. - HOLLENBERG, F.F.: Effects of benzyl isothiocyanate on rat and human cytochromes P450. Identification of metabolites formed by P4502B1. J Pharmacol Exp Ther., 2001, p. 198-206. 
12. CHUNG, F.L. - CONAWAY, C.C. - RAO, C.V. - BANDARU, S.R.: Chemoprevention of colonic aberrant crypt foci in Fischer rats by sulforaphane and phenethyl isothiocyanate. Carcinogenesis, 2000, p. 2287-2291.

13. LAMPE, J.W. - PETERSON, S.: Brassica, Biotransformation and Cancer Risk: Genetic Polymorphisms Alter the Preventive Effects of Cruciferous Vegetables, J. Nutr., 2002, p. 2991-2994.

14. Kensler, T.W. - EGNER, P.A. - WANG, J.B. - ZHU,Y.R. - ZHANG, B.C. LU, P.X. ET AL.: Chemoprevention of hepatocellular carcinoma in aflatoxin endemic areas. Gastroenterology, 2004, p. 310-318.

15. HECHT, S.S. - CARMELLA, S.G. - MURPHY, S.E.: Effects of watercress consumption on urinary metabolites of nicotine in smokers. Cancer Epidemiol Biomarkers Prev., 1999, p. 907-913.

16. MURRAY, S. - LAKE, B.G. - GRAY, S. - EDWARDS, A.J. - SPRINGALL, C. BOWEY, E.A. - WILLIAMSON, G. - BOOBIS, A.R. - GOODERHAM, N.J.: Effect of cruciferous vegetable consumption on heterocyclic aromatic amine metabolism in man. Carcinogenesis 22, 2001, p. 1413-1420.

17. SAFE, S. - SABITHA PAPINENI, S. - CHINTHARLAPALlI, S.: Cancer chemotherapy with indole-3-carbinol, bis(3'-indolyl)methane and synthetic analogs. Cancer Lett., 2008, p. 326-338.

18. BAIRD, W.M. - HOOVEN, L.A. - MAHADEVAN, B.: Carcinogenic polycyclic aromatic hydrocarbon - DNA adducts and mechanism of action. Environ Mol Mutagen, 2005, p. $106-114$.

19. REED, G.A. - PETERSON, K.S. - SMITH, H.J. ET AL.: A phase I study of indole-3carbinol in women: tolerability and effects. Cancer Epidemiol Biomarkers Prev., 2005, p. 1953-1960.

20. KIM, D.J. - LEE, K.K. - HAN, B.S. - AHN, B. - BAE, J.H. - JANG, J.J.: Biphasic modifying effect of indole-3-carbinol on diethylnitrosamine-induced preneoplastic glutathione S-transferase placental form-positive liver cell foci in Sprague-Dawley rats. Jpn J Cancer Res.,1994, p. 578-583.

21. STONER, G. - CASTO, B. - RALSTON, S. - ROEBUCK, B. - PEREIRA, C. BAILEY, G.: Development of a multi-organ rat model for evaluating chemopreventive agents: efficacy of indole-3-carbinol. Carcinogenesis, 2002, p. 265-272.

22. KIM, D.J. - HAN, B.S. - AHN, B. - HASEGAWA, R. - SHIRAI, T. - ITO N., ET AL.: Enhancement by indole-3-carbinol of liver and thyroid gland neoplastic development in a rat medium-term multiorgan carcinogenesis model. Carcinogenesis, 1997, p. 377-381.

23. YOSHIDA, M. - KATASHIMA, S. - ANDO, J. - TANAKA, T. - UEMATSU, F. NAKAE, D. ET AL.: Dietary indole-3-carbinol promotes endometrial adenocarcinoma development in rats initiated with $N$-ethyl- $N_{-}$-nitro- $N$-nitrosoguanidine, with induction of cytochrome P450s in the liver and consequent modulation of estrogen metabolism. Carcinogenesis, 2004, p. 2257-2264.

24. FOWKE, J.H. - LONGCOPE, C. - HERBERT, J.R.: Brassica vegetable consumption Shift estrogen metabolism in healthy postmenopausal women. Cancer Epidemiol. Biomarkers Prev, 2000, p. 773-779.

25. MUTI, P. - BRADLOW, M.L. - MICHELI, A. - KROGH, V. - FREUDENHEIM, J.L. - SHUNEMANN, H.J. - STANULLA, M. - YANG, J. - SEPKOVIC, D.W. TREVISAN, M.: Estrogen metabolism and risk of the breast cancer: a prospective study of the 2:16 [alpha]-hydroxyestrone ratio in pre-menopausal and post-menopausal women. Epidemiology, 2000, p. 635-640.

26. KRISTAL, A.R. - LAMPE, J.W.: Brassica vegetables and prostate cancer risk: a review of epidemiological evidence. Nutr Cancer, 2002, p. 1-9. 
27. FOWKE, J.H. - CHUNG, F.L. - JIN, F. - QI, D. - CAI, Q. - CONAWAY, C. CHENG, J.R. - SHU, X.O. - GAO, Y.T. - ZHENG, W.: Urinary isothiocyanate levels, brassica, and human breast cancer. Cancer Res., 2003, p. 3980-3986.

28. AGGARWAL, B.B. - ICHIKAWA, H.: Molecular targets and anticancer potential of indole-3-carbinol and its derivatives. Cell Cycle, 2005, 1201-1215.

29. CZAPSKI, J.: Cancer preventive properties of cruciferous vegetables. Vegetable Crops Research Bulletin, 2009, p. 5-18

30. MENG, Q. - YUAN, F. - GOLDBERG, I.D. - ROSEN, E.M. - AUBORN, K. - FAN, S.: Indole-3- carbinol is a negative regulator of estrogen receptor- $\alpha$ signalling in human tumour cells. J. Nutr., 2000, 2927-2931.

31. AUBORN, K.J. - ROSEN, E.M. - GOODWIN, L. - CHANDRASKAREN, A. WILLIAMS, D.E. - CHEN, D. - CARTER, T.H.: Indole-3-carbinol is negative regulator of estrogen. J. Nutr., 2003. p. 2470S-2475S.

32. CHANG, X. - TOU, J.C. - HONG, C. ET AL.: 3,3'-Diindolylmethane inhibits angiogenesis and the growth of transplantable human breast carcinoma in athymic mice. Carcinogenesis, 2005, p. 771-778.

33. BELL, M.C. - CROWLEY-NOWICK, P. - BRADLOW, H.L. - SEPKOVIC, D.W. SCHMIDT-GRIMMINGER, D. - HOWELL, P. - MAYEAUX, E.J. - TUCKER, A. TURBAT-HERRERA, E.A. - MATHIS, J.M.: Placebo-controlled trial on indole-3-carbinol in the treatment of CIN. Gynecologic Oncol., 2000, p. 123-129.

34. MISIEWICZ, I. - SKUPINSKA, K. - KASPRZYCKA-GUTTMAN, T.: Sulforaphane and 2-oxohexyl isothiocyanate induce cell growth arrest and apoptosis in L-1210 leukemia and ME-18 melanoma cells. Oncol Rep., 2003, p. 2045-2050.

35. SINGH, S.V. - ANTOSIEWICZ, A.H. - SINGH, A.V. - LEW, K.L. - SRIVASTAVA, S.K. - KAMATH, R. - BROWN, K.D. - ZHANG, L. - BASKARAN, R.: Sulforaphaneinduced G2/M Phase Cell Cycle Arrest Involves Checkpoint Kinase 2-mediated Phosphorylation of Cell Division Cycle 25C. J Biol Chem., 2004, p. 25813-25822.

36. CONAWAY, C.C. - JIAO, D. - CHUNG, F.L.: Inhibition of rat liver cytochrome P450 isozymes by isothiocyanates and their conjugates.: A structure - activity relationship study. Carcinogenesis, 1996, p. 2423-2427.

37. ROSE, P. - WHITEMAN, M. - HUANG, S.H. - HALLIWELL, B.: Beta-phenylethyl isothiocyanate-mediated apoptosis in hepatoma HepG2 cells. Cell Mol Life Sci, 2003, p.1489-1503.

38. ZHANG, Y.: Cancer-preventive isothiocyanates: measurement of human exposure and mechanism of action. Mutat Res., 2004, p. 173-190.

39. TANG, L. - ZHANG, Y.: Dietary isothiocyanates inhibit the growth of human bladder carcinoma cells. J Nutr., 2004, p. 2004-2010.

40. GARCIA, H.H. - BRAR, G.A. - NGUYEN, D.H. - BJELDANES, L.F. FIRESTONE, G.L.: Indole-3-carbinol (I3C) inhibits cyclin-dependent kinase-2 function in human breast cancer cells by regulating the size distribution, associated cyclin $\mathrm{E}$ forms, and subcellular localization of the CDK2 protein complex. J Biol Chem., 2005, p. 8756-8764.

41. CRAM, E.J. - LIU, B.D. - BJELDANES, L.F. - FIRESTONE, G.L.: Indole-3carbinol inhibits CDK6 expression in human MCF-7 breast cancer cells by disrupting Sp1 transcription factor interactions with a composite element in the CDK6 gene promoter. J Biol Chem., 2001, p. 22332- 2234.

42. COVER, C.M. - HSIEH, S.J. - TRAN, S.H. - HALLDEN, G. - BJELDANES, L.F. FIRESTONE, G.L.: Indole-3-carbinol inhibits the expression of cyclin-dependent kinase-6 and induces a G1 cell cycle arrest of human breast cancer cells independent of estrogen receptor signaling. J Biol Chem., 1998, p. 3838 - 3847.

43. KUTSCHY, P. - SALAYOVÁ, A. - CURILLOVÁ, Z. - KOZÁR, T. - MEZENCEV, R. - MOJZIS, J. - PILÁTOVÁ M. - BALENTOVÁ, E. - PAZDERA, P. - SABOL, M. - 
ZBUROVÁ, M.: 2-(substituted phenyl)amino analogs of 1-methoxyspirobrassinol methyl ether: synthesis and anticancer activity. Bioorg Med Chem., 2009, p. $3698-712$.

44. MEZENCEV, R. - KUTSCHY, P. - SALAYOVA, A. - UPDEGROVE, T. -

MCDONALD, J. F.: The design, synthesis and anticancer activity of new nitrogen mustard derivatives of natural indole phytoalexin 1-methoxyspirobrassinol. Neoplasma, 2009, p. 32130 .

45. PILÁTOVÁ, M. - KUTSCHY, P. - MOJŽIŠ, J. - ČURILLOVÁ, Z. - REPOVSKÁ, M. - ŠARIŠSKÝ, M. - MIROSSAY, A. - MEZENCEV, R. - MIROSSAY, L.: Camalexin and its derivate benzocamalexin with various substituents and their antiproliferative effect on different cancer cell lines. Biomed Papers, 2007, p. 69.

46. ČURILlOVÁ, Z. - SALAYOVÁ, A. - KUTSCHY, P. - MOJŽIŠ, J. - PILÁTOVÁ, M. - MEZENCEV, R. - RAKOVSKÁ, M. - BUDOVSKÁ, M. - KALIFA, M. - ZUBROVÁ M. - VÉGHOVÁ, I.: Cruciferous phytoalexins and their analogs: New compounds with promising anticancer activity. Synthetic and Natural Compounds in Cancer Therapy and Prevention, 2007, p. 78.

47. PILÁTOVÁ, M. - SARISSKÝ, M. - KUTSCHY, P. - MIROSSAY, A. MEZENCEV, R. - CURILLOVÁ, Z. - SUCHÝ, M. - MONDE, K. - MIROSSAY, L. MOJZIS J.: Cruciferous phytoalexins: antiproliferative effects in T-Jurkat leukemic cells. Leuk Res., 2005, p. 415-21.

48. KUNIMASA, K. - KOBAYASHI, T. - KAJI, K. - OHTA, T.: Antiangiogenic effects of indole-3-carbinol and 3,3'-diindolylmethane are associated with their differential regulation of ERK1/2 and Akt in tube-forming HUVEC. J Nutr., 2010, p. 1-6.

49. RIBY, J.E. - FIRESTONE, G.L. - BJELDANES, L.F.: 3,3'-diindolylmethane reduces levels of HIF-1alpha and HIF-1 activity in hypoxic cultured human cancer cells. Biochem Pharmacol., 2008, p. 1858-1867.

50. XIAO, D. - SINGH, S.V.: Phenethyl isothiocyanate inhibits angiogenesis in vitro and ex vivo. Cancer Res., 2007, p. 2239-2246.

51. JUGE, N. - MITHEN, R. F. - TRAKA, M.: Molecular basis for chemoprevention by sulforaphane a comprehensive review. Cell Mol Life Sci., 2007, p. 1105-1127.

52. BERTL, E. - BARTSCH, H. - GERHAUSER, C.: Inhibition of angiogenesis and endothelial cell function are novel sulforaphane-mediated mechanisms in chemoprevention. Mol Cancer Ther., 2006, p. 575-585.

53. DAVIS, R. - SINGH, K.P. - KURZROCK, R. - SHANKAR, S.: Sulforaphane inhibits angiogenesis through activation of FOXO transcription factors. Oncol Rep., 2009, p. 14731478.

54. HECHT, S.S. - CARMELLA, S.G. - KENNEY, P.M. - LOW, S.H. - ARAKAWA, K. - YU, M.C.: Effects of cruciferous vegetable consumption on urinary metabolites of the tobacco-specific lung carcinogen 4-(methylnitrosamino)-1-(3-pyridyl)-1-butatone in Singapore Chinese. Cancer Epidemiol Biomarkers, 2004, p. 997-1004.

55. CONAWAY, C.C. - YANG, Y.M. - CHUNG, F.L.: Isothiocyanates as cancer chemopreventive agents: their biological activities and metabolism in rodents and humans. Curr Drug Metab., 2002, p. 233-255.

Registered: March 24, 2011

Accepted: May 27, 2011
MVDr. Martina Pilátová, PhD.

University of P.J.Safarik

Department of Pharmacology

Tr. SNP 1

04066 Kosice,

Slovakia

martina.pilatova@upjs.sk 


\title{
KAPUSTOVITÁ ZELENINA V PREVENCII NÁDOROVÝCH OCHORENÍ
}

Pilátová, M. - Chripková, M. - Mojžiš, J.

Ústav farmakológie, Lekárska fakulta, UPJŠ, Košice

\begin{abstract}
Epidemiologické štúdie zaznamenali výraznú inverznú koreláciu medzi príjmom kapustovitej zeleniny a rizikom vzniku rakoviny. Táto spojitost' sa ukázala byt' silnejšou ako spojitost' medzi rizikom vzniku rakoviny a príjmom ovocia a zeleniny všeobecne. Kapustovitá zelenina je jedinečným a bohatým zdrojom glukozinolátov. Glukozinoláty same o sebe nemajú biologickú aktivitu, ale ich hydrolytické produkty majú protinádorové a zdraviu prospešné vlastnosti. Výsledkom hydrolytickej degradácie glukozinolátov je tvorba biologicky aktívnych látok, ako sú indoly (napr.: I3C - indol - 3 karbinol, DIM - diindolylmetán, indolové fytoalexíny) a izotiokyanáty (napr.: PEITC - fenetyl isotiokyanát, sulforafán (SFN). Bolo popísaných niekol'ko mechanizmov chemopreventívneho pôsobenia kapustovitej zeleniny ako vplyv na biotransformačný systém, indukcia blokády bunkového cyklu a apoptózy, antiangiogénny účinok. Bola popísaná priaznivá modulácia metabolizmu estrogénov po podávaní DIM a I3C. Napriek všetkým zdraviu prospešným očakávaniam niekol'ko štúdií zaznamenalo, že I3C inicioval a podporoval rozvoj nádorových ochorení, ak bol dlhodobo podávaný potkanom po aplikácii karcinogénu (postiniciačne). Pretože vplyv dlhodobého používania spomínaných látok na riziko vzniku nádorových ochorení nie je známy, mali by sme sa vyhýbat rozsiahlemu užívaniu potravinových doplnkov obsahujúcich prírodné látky, až kým nebudú lepšie pochopené potenciálne riziká aj benefity.
\end{abstract}

Acta Facult. Pharm. Univ. Comenianae, 2011, p. 62 - 71. 